\title{
ANALISIS PELEBARAN PUNCAK DIFRAKSI SINAR-X PADA PASIR BESI TITAN YOGYAKARTA: UKURAN KRISTALIT, REGANGAN KISI DAN PROBABILITAS MINERAL
}

\author{
Analysis of X-ray Diffraction Line Broadening for Yogyakarta \\ Titaniferous Iron Sand: Crystallite Size, Lattice Strain and Mineral \\ Probability
}

\section{IBRAHIM PURAWIARDI}

Pusat Penelitian Metalurgi dan Material, Lembaga Ilmu Pengetahuan Indonesia (LIPI), Kawasan Pusat Penelitian Ilmu Pengetahuan dan Teknologi (PUSPIPTEK) Gd. 470, Tangerang Selatan 15314, Banten e-mail : ibrahimpurawiardi@gmail.com

\begin{abstract}
ABSTRAK
Pasir besi titan Yogyakarta mengandung berbagai jenis mineral baik berupa mineral bijih (mengandung Fe dan Ti) maupun mineral non-bijih (tidak mengandung Fe dan Ti). Mineral-mineral tersebut dapat diidentifikasi menggunakan difraksi sinar-x (XRD). Namun, karakterisasi XRD memiliki kesulitan tersendiri dalam analisis mineral karena selalu muncul ambiguitas fasa mineral dalam satu puncak difraksi yang sama. Hal ini dapat menimbulkan ketidakpastian dalam identifikasi mineral pada pasir besi titan. Untuk menghindari hal tersebut, diperlukan suatu metode analisis XRD yang lebih khusus. Tujuan studi ini adalah memperkenalkan metode tersebut yaitu metode analisis pelebaran puncak difraksi Willimason-Hall. Percontoh yang digunakan pada studi ini adalah serbuk pasir besi titan Yogyakarta. Percontoh tersebut dikarakterisasi dengan difraktometer sinar-x (XRD) untuk dianalisis pelebaran puncak difraksinya berdasarkan nilai lebar setengah puncak difraksi (FWHM). Hasil analisis pelebaran puncak ini digunakan untuk menentukan regangan kisi, ukuran kristalit dan probabilitas mineralnya. Dari hasil analisis pelebaran puncak difraksi menunjukkan terdapat empat variasi regangan kisi yaitu 0,$0061 ; 0,0045 ; 0,0006$; dan 0,006 serta tiga variasi ukuran kristalit yaitu 2703, 568, dan $124 \mathrm{~nm}$. Dari keempat variasi regangan kisi dan tiga variasi ukuran kristalit tersebut, didapatkan dua probabilitas mineral bijih (magnetit dan ilmenit) serta tiga probabilitas mineral non-bijih (nefelin, lueneburgit dan albit tingkat tinggi).
\end{abstract}

Kata kunci: pasir besi titan, pelebaran puncak difraksi, regangan kisi, ukuran kristalit, probabilitas mineral.

\begin{abstract}
A titaniferous iron sand from Yogyakarta consists of some ores (Fe, Ti-containing minerals) and non-ore minerals (non Fe and Ti). The minerals can be identified by $\mathrm{x}$-ray diffraction (XRD). However, a mineral phase ambiguity on a diffraction peak always happen. This problem can make an uncertainty in its mineral identification. For solving the problem, a special XRD analytical method is needed. The aim of this study is presenting this method by means of $x$-ray line broadening analysis using Williamson-Hall method. A titaniferous iron sand powder from Yogyakarta was used as a sample of this study. This sample then was characterized by x-ray diffractometer (XRD) to analyze its line broadening based on full width at the half maximum (FWHM) value. The analysis results then were used for determining lattice strain, crystallite size and mineral probabilities. The line broadening analysis results showed
\end{abstract}


that there were four variations of lattice strains $(0.0061,0.0045,0.0006$, and 0.006) and three variations of crystallite sizes $(2703 \mathrm{~nm}, 568 \mathrm{~nm}$, and $124 \mathrm{~nm}$ ). From these variations, two variations of ore minerals (magnetite and ilmenite) and three variations of non-ore minerals (nepheline, lueneburgite, and high albite) were determined.

Keywords: titaniferous iron sand, line broadening, lattice strain, crystallite size, mineral probabilities.

\section{PENDAHULUAN}

Pasir besi titan daerah selatan Yogyakarta diduga merupakan salah satu sumber mineral magnetit $\left(\mathrm{Fe}_{3} \mathrm{O}_{4}\right)$ dan ilmenit $\left(\mathrm{FeTiO}_{3}\right)$ yang potensial di Indonesia (Purawiardi, Purawiardi dan Firdiyono, 2020). Untuk memastikan mineral-mineral apa saja yang terkandung di dalamnya, pengujian komposisinya perlu dilakukan dengan berbagai alat karakterisasi material. Namun, karena adanya perbedaan limitasi dalam identifikasinya, terdapat perbedaan mineral yang dapat dideteksi dan yang tidak dapat dideteksi pada masing-masing alat karakterisasi material. Oleh sebab itu, untuk mengidentifikasi kandungan mineralmineral di dalam pasir besi titan Yogyakarta tidak mungkin hanya dilakukan oleh satu alat karakterisasi saja. Sehingga, identifikasi dari berbagai alat karakterisasi material terhadap percontoh pasir besi titan dari Yogyakarta ini dapat digabungkan untuk interpretasi mineral secara keseluruhan.

Studi sebelumnya (Purawiardi, Purawiardi dan Firdiyono, 2020) telah melakukan analisis probabilitas kandungan mineral pada pasir besi titan Yogyakarta menggunakan alat portable $x$ ray fluorescence (pXRF). Dari analisis pXRF tersebut, terdeteksi tiga mineral bijih yaitu magnetit, ilmenit, dan hematit; serta lima mineral non-bijih yaitu hipersten, augit, kuarsa, biotit dan albit. Pada studi kali ini, analisis probabilitas mineral dilakukan menggunakan alat karakterisasi difraktometer sinar-x (XRD). Probabilitas mineral ditentukan berdasarkan fasa yang teridentifikasi. Namun, terdapat kesulitan tersendiri dalam mengidentifikasi fasa mineral menggunakan XRD, yaitu banyaknya kemungkinan ambiguitas fasa dalam satu puncak difraksi karena keidentikan nilai jarak antar bidang sejenis $(d)$ antara berbagai kemungkinan fasa (Kumar, 2017). Untuk mengurangi masalah ambiguitas fasa tersebut, pada studi ini pemilahan fasa dilakukan terlebih dahulu menggunakan analisis karakteristik regangan kisi dan ukuran kristalit. Kedua analisis tersebut dapat dilakukan dengan mudah menggunakan analisis pelebaran puncak difraksi sinar-x dengan teknik plot Williamson-Hall.

Kelebihan teknik plot Williamson-Hall adalah dapat mendeteksi kelompok puncak difraksi yang memiliki kesamaan nilai regangan kisi dan ukuran kristalit. Kesamaan nilai dua parameter ini adalah indikator dari probabilitas fasa mineral yang sama. Kekurangan metode plot Williamson-Hall adalah tidak dapat dilakukan pada seluruh puncak difraksi yang terdeteksi, namun hanya terbatas pada puncak-puncak difraksi yang mengalami pelebaran puncak akibat efek regangan kisi dan perbedaan ukuran kristalit saja.

\section{Plot Williamson-Hall}

Plot Williamson-Hall merupakan teknik yang saat ini paling banyak digunakan untuk menganalisis pelebaran puncak difraksi sinar-x (Kulkarni dan Mathad, 2018; Pushkarev, Grekhov dan Zenchenko, 2018; Aarif UI Islam dan Ikram, 2019; Erdoğan, 2019; Kafashan, 2019; Madhavi, 2019; Norouzzadeh $d k k$., 2020; Dey dan Das, 2021). Prinsipnya adalah pelebaran puncak difraksi sinar-x merupakan gabungan antara efek ukuran kristalit dan efek regangan kisi.

Pelebaran puncak difraksi sinar-x akibat dari efek ukuran kristalit sendiri dirumuskan dalam sebuah hubungan persamaan Scherrer (Kafashan, 2019) berikut:

$\mathrm{B}_{\mathrm{C}}=\frac{\mathrm{k} \lambda}{\mathrm{L} \operatorname{Cos} \theta}$

dengan $B c$ adalah pelebaran puncak difraksi akibat efek ukuran kristalit (radian), $k$ adalah konstanta, $\lambda$ adalah panjang gelombang incident beam sinar-x (nm), $L$ adalah ukuran kristalit (nm) dan $\theta$ adalah sudut difraksi dalam derajat.

Sedangkan pelebaran puncak difraksi sinar-x akibat efek regangan kisi ( $B s$, dalam radian) dirumuskan dalam sebuah persamaan (Kafashan, 2019) berikut: 
$\mathrm{B}_{\mathrm{S}}=4 \varepsilon \tan \theta$

dengan $\varepsilon$ adalah regangan kisi.

Jika digabungkan antara $B_{C}$ dan $B_{s}$ akan didapatkan nilai pelebaran puncak difraksi sinar-x secara keseluruhan $(B$, dalam radian) yang dapat dirumuskan menjadi,

$\mathrm{B}=\mathrm{B}_{\mathrm{C}}+\mathrm{B}_{\mathrm{S}}$

$\mathrm{B}=\frac{\mathrm{k} \lambda}{\mathrm{L} \operatorname{Cos} \theta}+4 \varepsilon \tan \theta$

$B \operatorname{Cos} \theta=\frac{k \lambda}{L}+4 \varepsilon \operatorname{Sin} \theta$

Persamaan (5) yang merupakan persamaan hasil penyederhanaan akhir dapat dianggap sebagai persamaan linier $y=a x+b$ dengan $y$ adalah $B \operatorname{Cos} \theta, x$ adalah $\operatorname{Sin} \theta$, a adalah $4 \varepsilon$, serta $b$ adalah $(k \lambda L)$. Agar analisis lebih mudah dilakukan, plot Williamson-Hall dapat dibuat dengan absis (sumbu-x) adalah $\operatorname{Sin} \theta$ dan ordinat (sumbu-y) adalah $B \operatorname{Cos} \theta$, sehingga dengan plot Williamson-Hall ini, nilai regangan kisi $(\varepsilon)$ dapat diperoleh dari gradien persamaan garis regresi liniernya dibagi 4 (empat), dan ukuran kristalit $(L)$ dapat diperoleh dari nilai $(k \lambda L)$ yang merupakan nilai titik potong pada ordinat.

Di dalam perhitungannya, pelebaran puncak difraksi $(B)$ dihitung dari besarnya nilai lebar setengah puncak difraksi (FWHM) dalam satuan ${ }^{\circ} 2 \theta$. Satuan ${ }^{\circ} 2 \theta$ ini kemudian dikonversi menjadi satuan radian (rad). Ilustrasi FWHM sendiri dapat dilihat pada Gambar 1, dengan nilai yang diukur dari lebar puncak difraksi pada posisi setengah ketinggiannya.

Hal yang perlu diperhatikan dalam analisis ini adalah nilai regangan kisi dan ukuran kristalit yang diperoleh bukanlah nilai yang mutlak, namun berupa nilai relatif untuk dibandingkan satu sama lain.

\section{METODE}

Percontoh merupakan serbuk pasir besi titan yang diperoleh dari daerah selatan Yogyakarta sebanyak 3 gram. Percontoh tersebut digerus hingga halus (-200 mesh) menggunakan mortar agate.

Percontoh selanjutnya dikarakterisasi menggunakan difraktometer sinar-x (XRD) merek Malvern PANalytical tipe Aeris (Cu-Ka, $\lambda=1,5406 \AA$ ) menggunakan rentang sudut $2 \theta$ mulai dari $5^{\circ}$ hingga $85^{\circ}$. Kalkulasi data difraksi kemudian dilakukan menggunakan perangkat lunak Highscore Plus (HSP).

Hasil kalkulasi kemudian digunakan untuk menganalisis pelebaran puncak difraksinya menggunakan metode plot Williamson-Hall. Selanjutnya, hasil analisis plot Williamson-Hall yang berupa regangan kisi dan ukuran kristalit dijadikan dasar dalam menentukan probabilitas mineralnya.

Tabel 1. Data difraksi percontoh yang merupakan hasil kalkulasi menggunakan perangkat lunak HSP

\begin{tabular}{ccccr}
\hline$\lambda=1,5406 \AA(\mathrm{Cu}-\mathrm{K} \alpha)$ & & & \\
\hline No. Puncak & $2 \theta\left(^{\circ}\right)$ & $d(\AA)$ & $\mathrm{FWHM}\left({ }^{\circ} 2 \theta\right)$ & $\mathrm{I} / \mathrm{l}_{\mathrm{o}}(\%)$ \\
\hline 1 & 10,4450 & 8,4626 & 0,0649 & 22,96 \\
2 & 13,5966 & 6,5073 & 0,2598 & 5,70 \\
3 & 18,2121 & 4,8672 & 0,1732 & 8,78 \\
4 & 18,8466 & 4,7048 & 0,1299 & 6,55 \\
5 & 19,8249 & 4,4748 & 0,1299 & 8,45 \\
6 & 21,8860 & 4,0578 & 0,0866 & 27,36 \\
7 & 22,7334 & 3,9084 & 0,2598 & 6,04 \\
8 & 23,5794 & 3,7701 & 0,0866 & 36,67 \\
9 & 24,3751 & 3,6488 & 0,2165 & 10,60 \\
10 & 26,4562 & 3,3663 & 0,2598 & 5,51 \\
11 & 27,5149 & 3,2391 & 0,0649 & 70,91 \\
12 & 27,6837 & 3,2197 & 0,0866 & 77,64 \\
13 & 27,9423 & 3,1905 & 0,1082 & 100,00 \\
14 & 28,4335 & 3,1365 & 0,0866 & 18,75 \\
15 & 29,7453 & 3,0011 & 0,1299 & 47,77 \\
16 & 30,0032 & 2,9759 & 0,0866 & 30,66 \\
17 & 30,2411 & 2,9530 & 0,0866 & 50,50 \\
\hline
\end{tabular}




\begin{tabular}{|c|c|c|c|c|}
\hline \multicolumn{5}{|c|}{$\lambda=1,5406 \AA(\mathrm{Cu}-\mathrm{K} \alpha)$} \\
\hline No. Puncak & $2 \theta\left({ }^{\circ}\right)$ & $d(\AA)$ & FWHM $\left({ }^{\circ} 2 \theta\right)$ & $\mathrm{I} / \mathrm{I}_{\mathrm{o}}(\%)$ \\
\hline 18 & 30,7388 & 2,9063 & 0,0866 & 22,43 \\
\hline 19 & 31,7528 & 2,8158 & 0,0649 & 11,25 \\
\hline 20 & 32,9122 & 2,7192 & 0,3464 & 5,41 \\
\hline 21 & 34,8761 & 2,5705 & 0,1299 & 12,35 \\
\hline 22 & 35,3386 & 2,5379 & 0,1082 & 45,13 \\
\hline 23 & 35,6426 & 2,5169 & 0,0649 & 33,98 \\
\hline 24 & 37,0696 & 2,4232 & 0,5196 & 4,89 \\
\hline 25 & 39,1434 & 2,2995 & 0,0649 & 11,48 \\
\hline 26 & 41,8698 & 2,1558 & 0,1299 & 9,21 \\
\hline 27 & 42,9656 & 2,1034 & 0,1732 & 14,73 \\
\hline 28 & 44,2930 & 2,0434 & 0,1299 & 7,66 \\
\hline 29 & 45,2703 & 2,0015 & 0,5196 & 4,56 \\
\hline 30 & 49,6060 & 1,8362 & 0,5196 & 3,80 \\
\hline 31 & 52,0867 & 1,7545 & 0,0792 & 47,96 \\
\hline 32 & 52,2322 & 1,7499 & 0,0792 & 28,05 \\
\hline 33 & 53,3311 & 1,7164 & 0,3168 & 5,54 \\
\hline 34 & 56,8650 & 1,6179 & 0,7392 & 13,99 \\
\hline 35 & 59,5704 & 1,5507 & 0,1056 & 14,90 \\
\hline 36 & 61,9949 & 1,4957 & 0,0792 & 22,28 \\
\hline 37 & 62,3212 & 1,4887 & 0,0792 & 38,36 \\
\hline 38 & 64,0498 & 1,4526 & 0,6336 & 3,96 \\
\hline 39 & 73,9504 & 1,2807 & 0,6336 & 4,05 \\
\hline
\end{tabular}

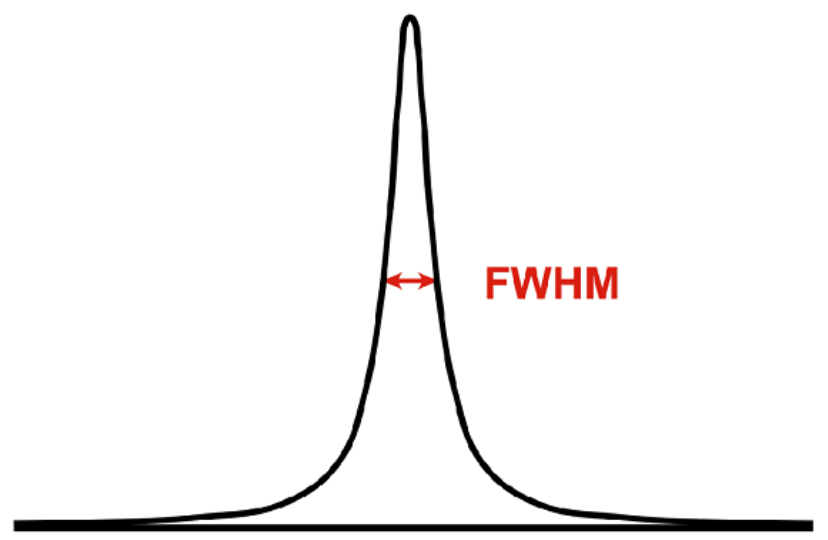

Gambar 1. Ilustrasi posisi lebar setengah puncak difraksi sinar-x (FWHM).

\section{HASIL DAN PEMBAHASAN}

Hasil kalkulasi XRD menggunakan perangkat lunak HSP dapat dilihat pada Tabel 1. Pada tabel tersebut terdapat nilai-nilai $\lambda$, nomor

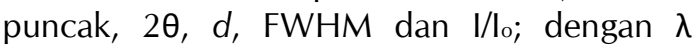
merupakan besar panjang gelombang incident beam yang digunakan, nomor puncak merupakan urutan puncak difraksi, $2 \theta$ merupakan sudut Bragg (sudut difraksi) yang terbentuk, $d$ adalah jarak antar bidang, FWHM adalah lebar setengah puncak (Gambar 1), dan $\mathrm{l} /$ lo adalah tinggi puncak difraksi yang berupa nilai intensitas relatif (dengan nilai tertinggi dianggap sebagai 100).
Untuk menganalisis pelebaran puncak difraksi, parameter penting yang digunakan adalah $2 \theta$ dan FWHM (Suryanarayana dan Norton, 1998; Pratapa dan O'Connor, 2002). Selanjutnya, nilai-nilai $2 \theta$ dan FWHM ini digunakan untuk membuat plot FWHM vs $2 \theta$ seperti yang ditunjukkan pada Gambar 2.

Plot FWHM vs $2 \theta$ pada Gambar 2 digunakan untuk memilah dan mengeliminasi puncakpuncak difraksi yang terdapat pengaruh regangan kisi dan ukuran kristalit dalam pelebaran puncak difraksinya. Identifikasi kemudian dilakukan dengan analisis garis regresi liniernya. Di dalam membuat garis 
regresi linier, terdapat kriteria yang penting, yaitu $R^{2}$. Nilai $R^{2}$ ini menunjukkan korelasi antara absis dan ordinat. Idealnya, korelasi absis dan ordinat yang baik adalah $R^{2}=1$ yang menunjukkan bahwa variabel ordinat merupakan $100 \%$ fungsi variabel absis. Namun, jarang ditemukan kondisi ideal tersebut, sehingga kisaran $0.9<R^{2}<1$ sudah dapat diterima untuk pembentukkan satu garis regresi linier dengan korelasi ordinat dan absis yang valid (> 90\%). Pada Gambar 2.a, garisgaris regresi linier yang terbentuk memiliki karakteristik tanpa gradien (gradien nol). Pada Gambar 2.b, garis regresi linier yang terbentuk memiliki karakteristik gradien bernilai negatif. Sedangkan pada Gambar 2.c, garis-garis regresi linier yang terbentuk memiliki gradien yang bernilai positif. Berdasarkan literatur (Suryanarayana dan Norton, 1998), efek regangan kisi dan ukuran kristalit akan menyebabkan terbentuknya pola garis linier dengan gradien positif dari rentang sudut $2 \theta$ pada $0^{\circ}-100^{\circ}$. Dengan demikian, hanya plotplot puncak difraksi pada Gambar 2.c saja yang memiliki pengaruh regangan kisi dan ukuran kristalit, sehingga dapat dilanjutkan pada analisis plot Williamson-Hall. Sementara itu, plot-plot puncak difraksi pada Gambar 2.a dan Gambar 2.b tereliminasi.

Pada Gambar 2.c tersebut, terdapat empat garis regresi linier yang terbentuk. Masing-masing garis regresi linier memiliki persamaan garis regresi linier dan nilai $R^{2}$. Untuk memudahkan analisis dengan metode plot Williamson-Hall, keempat garis tersebut dikelompokkan menjadi Kelompok A, B, C dan D dengan kriteria persamaan garis regresi linier dan $R^{2}$ berdasarkan hasil plot pada Gambar 2.c. Pengelompokan ini kemudian dirangkum pada Tabel 2.
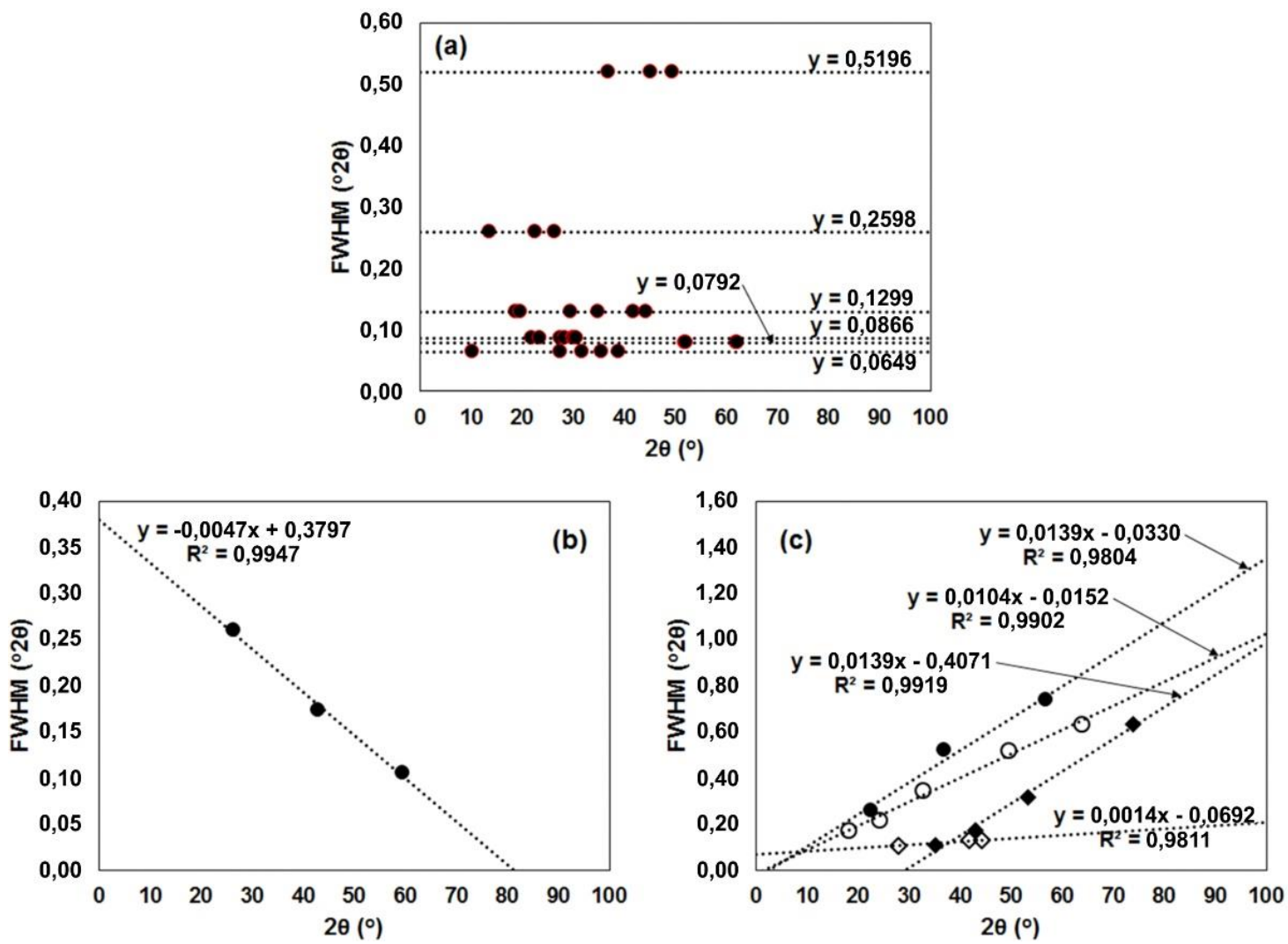

Gambar 2. Garis-garis regresi linier yang terbentuk berdasarkan plot FWHM vs 2ө. (a) Gradien bernilai nol. (b) Gradien bernilai negatif. (c) Gradien bernilai positif. 
Tabel 2. Pengelompokkan berdasarkan empat garis regresi linier yang terbentuk pada Gambar 2.c

\begin{tabular}{ccc}
\hline Kelompok & Persamaan Garis Regresi Linier & $R^{2}$ \\
\hline A & $y=0,0139 x-0,0330$ & 0,9804 \\
B & $y=0,0104 x-0,0152$ & 0,9902 \\
C & $y=0,0014 x+0,0692$ & 0,9811 \\
D & $y=0,0139 x-0,4071$ & 0,9919 \\
\hline
\end{tabular}

Puncak-puncak difraksi yang berkontribusi dalam pembentukkan garis regresi linier pada Kelompok A, B, C dan D kemudian diplotkan kembali dalam bentuk plot Williamson-Hall. Hasil plot Williamson-Hall pada keempat kelompok ini dapat dilihat pada Gambar 3. Dari plot Williamson-Hall akan dihasilkan kembali pola garis regresi linier dengan persamaan $y=a x+b$. Nilai a menunjukkan nilai 4ع (Kulkarni dan Mathad, 2018; Pushkarev, Grekhov dan Zenchenko, 2018; Aarif UI Islam dan Ikram, 2019; Erdoğan, 2019; Kafashan, 2019; Madhavi, 2019; Norouzzadeh $d k k ., 2020$; Dey dan Das, 2021), sedangkan nilai $b$ menunjukkan nilai $k \lambda / L$ (Suryanarayana dan Norton, 1998).

Nilai regangan kisi $(\varepsilon)$ kemudian dihitung berdasarkan nilai $4 \varepsilon$ yang diperoleh. Sedangkan nilai $b=k \lambda L$ digunakan untuk menghitung ukuran kristalit (L). Di dalam menghitung ukuran kristalit, nilai $\lambda$ yang digunakan sesuai dengan incident beam dari tube $\mathrm{Cu}-\mathrm{K} \alpha$ yang digunakan, yaitu $1,5406 \AA$ (=0,15406 nm), sementara nilai $k$ yang digunakan adalah 1 (satu). Kemudian, untuk memudahkan analisis selanjutnya, hasil perhitungan regangan kisi $(\varepsilon)$ dan ukuran kristalit (L) pada masing-masing kelompok ini kemudian dirangkum pada Tabel 3.

Seperti yang telah disebutkan sebelumnya, nilai regangan kisi dan ukuran kristalit ini bukan nilai mutlak, namun berupa nilai yang bersifat relatif karena hingga saat ini belum dapat dipastikan berapa nilai akurasinya. Oleh karena itu, nilainilai ini hanya dapat digunakan untuk dibandingkan satu sama lain (komparasi). Selanjutnya, Tabel 3 memperlihatkan pada kolom ukuran kristalit, nilai ukuran kristalit pada kelompok D bernilai negatif (tepatnya $-27 \mathrm{~nm}$ ). Nilai negatif ini hanya berupa nilai relatif yang menunjukkan hampir tidak adanya pengaruh ukuran kristalit dalam pelebaran puncak difraksinya, sehingga pada kelompok D hanya terdapat pengaruh regangan kisi saja pada pelebaran puncak difraksinya.
Hasil analisis (Tabel 3) menunjukkan bahwa setiap kelompok memiliki perbedaan nilai regangan kisi dan ukuran kristalit. Perbedaan ini memunculkan dugaan kuat bahwa probabilitas fasa mineralnya pun pastinya berbeda-beda pula. Namun, untuk membuktikannya, perlu dilakukan analisis fasa mineral pada masingmasing kelompok tersebut. Untuk menganalisis fasa mineral, diperlukan data nilai $d$ (lihat kolom ketiga pada Tabel 1).

Teknik analisis fasa mineral dilakukan dengan cara membandingkan kecocokkan nilai $d$ antara hasil pengujian XRD dengan nilai $d$ pada referensi fasa (PDF/ICDD) dengan toleransi nilai $\pm 0.01 \AA$ (Suryanarayana dan Norton, 1998). Hasil analisis fasa pada Kelompok A, B, C, dan D berturut-turut dapat dilihat pada Tabel 4 hingga 8. Dari analisis fasa, diketahui bahwa probabilitas fasa pada Kelompok A, B, dan C secara berturut-turut adalah $\mathrm{Na}_{3} \mathrm{~K}(\mathrm{Al}, \mathrm{Si})_{8} \mathrm{O}_{16}$, $\mathrm{Mg}_{3} \mathrm{~B}_{2}(\mathrm{OH})_{6}\left(\mathrm{PO}_{4}\right)_{2}\left(\mathrm{H}_{2} \mathrm{O}\right)_{6}$ dan $(\mathrm{Na}, \mathrm{K}) \mathrm{AlSi}_{3} \mathrm{O}_{8}$. Sedangkan pada Kelompok D terdapat dua probabilitas fasa sekaligus yaitu $\mathrm{Fe}_{3} \mathrm{O}_{4}$ (Tabel 7) dan $\mathrm{FeTiO}_{3}$ (Tabel 8). Jika dikelompokkan berdasarkan nama mineralnya, probabilitas mineral kelompok $A$ hingga $C$ secara berturutturut adalah nefelin, lueneburgit dan albit tingkat tinggi. Sementara dua probabilitas mineral pada kelompok $\mathrm{D}$ adalah magnetit $\left(\mathrm{Fe}_{3} \mathrm{O}_{4}\right)$ dan ilmenit $\left(\mathrm{FeTiO}_{3}\right)$.

Kandungan logam $\mathrm{Fe}$ dan $\mathrm{Ti}$ merupakan kandungan utama yang akan diekstrak melalui serangkaian proses metalurgi ekstraksi. Oleh sebab itu, mineral-mineral yang mengandung Fe dan Ti merupakan mineral bernilai ekonomis utama (mineral bijih) pada pasir besi titan Yogyakarta. Dengan demikian, mineral magnetit yang mengandung Fe serta mineral ilmenit yang mengandung $\mathrm{Fe}$ dan $\mathrm{Ti}$ dapat digolongkan sebagai mineral bijih. Sementara itu, mineral-mineral yang teridentifikasi lainnya yaitu nefelin, lueneburgit, dan albit tingkat tinggi yang tidak mengandung unsur Fe maupun Ti dapat dikategorikan sebagai mineral non-bijih pada pasir besi titan Yogyakarta ini. 

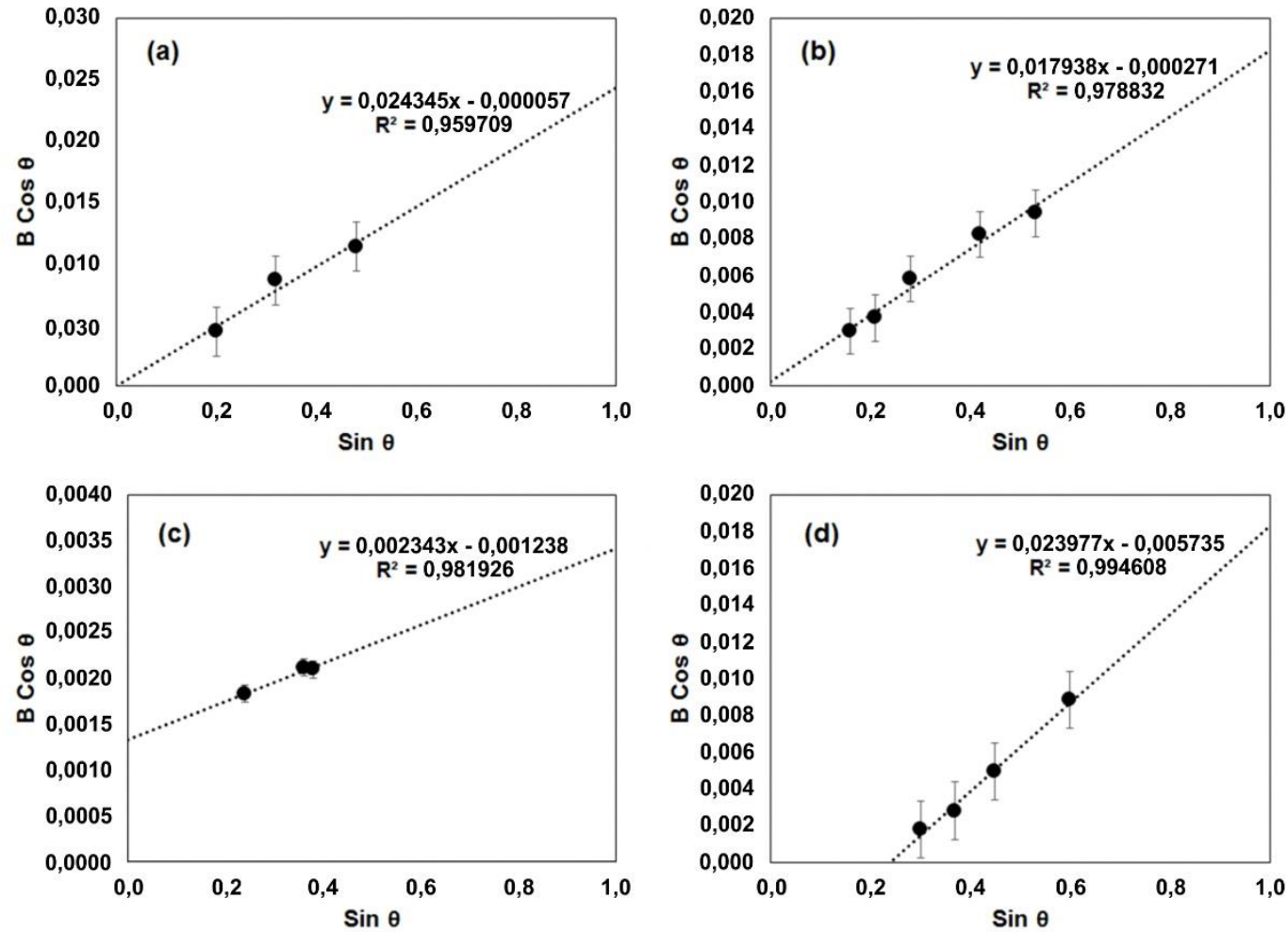

Gambar 3. Plot Williamson-Hall dengan garis regresi linier bergradien positif. (a) Kelompok A. (b) Kelompok B. (c) Kelompok C. (d) Kelompok D. Keterangan: error bar menunjukkan 1 x standard deviasi.

Tabel 3. Hasil kalkulasi nilai relatif regangan kisi dan ukuran kristalit.

\begin{tabular}{ccc}
\hline Kelompok & Regangan Kisi & Ukuran Kristalit $(\mathrm{nm})$ \\
\hline A & 0,0061 & 2703 \\
B & 0,0045 & 568 \\
C & 0,0006 & 124 \\
D & 0,0060 & -27 \\
\hline
\end{tabular}

Tabel 4. Analisis probabilitas fasa pada kelompok A.

\begin{tabular}{cccccc}
\hline \multicolumn{2}{c}{ Observasi } & \multicolumn{3}{c}{ Referensi } \\
\hline $\begin{array}{c}\text { No. } \\
\text { Puncak }\end{array}$ & $d(\AA)$ & $d(\AA)$ & $h k l$ & Fasa & No. Referensi \\
\hline 7 & 3,9084 & 3,8971 & 201 & $\mathrm{Na}_{3} \mathrm{~K}(\mathrm{Al}, \mathrm{Si})_{8} \mathrm{O}_{16}$ & PDF \# 76-2467 \\
24 & 2,4232 & 2,4283 & 221 & $\mathrm{Na}_{3} \mathrm{~K}(\mathrm{Al}, \mathrm{Si})_{8} \mathrm{O}_{16}$ & PDF \# 76-2467 \\
34 & 1,6179 & 1,6220 & 502 & $\mathrm{Na} 3 \mathrm{~K}(\mathrm{Al}, \mathrm{Si})_{8} \mathrm{O}_{16}$ & PDF \# 76-2467 \\
\hline
\end{tabular}

Tabel 5. Analisis probabilitas fasa pada kelompok B

\begin{tabular}{cccccc}
\hline \multicolumn{2}{c}{ Observasi } & \multicolumn{4}{c}{ Referensi } \\
\hline No. Puncak & $d(\AA)$ & $d(\AA)$ & $h k l$ & Fasa & No. Referensi \\
\hline 3 & 4,8672 & 4,8594 & 020 & $\mathrm{Mg}_{3} \mathrm{~B}_{2}(\mathrm{OH})_{6}\left(\mathrm{PO}_{4}\right)_{2}\left(\mathrm{H}_{2} \mathrm{O}\right)_{6}$ & PDF \# 80-1773 \\
9 & 3,6488 & 3,6390 & 120 & $\mathrm{Mg}_{3} \mathrm{~B}_{2}(\mathrm{OH})_{6}\left(\mathrm{PO}_{4}\right)_{2}\left(\mathrm{H}_{2} \mathrm{O}\right)_{6}$ & PDF \# 80-1773 \\
20 & 2,7192 & 2,7288 & $\overline{1} 22$ & $\mathrm{Mg}_{3} \mathrm{~B}_{2}(\mathrm{OH})_{6}\left(\mathrm{PO}_{4}\right)_{2}\left(\mathrm{H}_{2} \mathrm{O}\right)_{6}$ & PDF \# 80-1773 \\
30 & 1,8362 & 1,8314 & $0 \overline{4} 2$ & $\mathrm{Mg}_{3} \mathrm{~B}_{2}(\mathrm{OH})_{6}(\mathrm{PO})_{2}\left(\mathrm{H}_{2} \mathrm{O}\right)_{6}$ & PDF \# 80-1773 \\
38 & 1,4526 & 1,4517 & $\overline{1} \overline{2} 4$ & $\mathrm{Mg}_{3} \mathrm{~B}_{2}(\mathrm{OH})_{6}(\mathrm{PO})_{2}\left(\mathrm{H}_{2} \mathrm{O}\right)_{6}$ & PDF \# 80-1773 \\
\hline
\end{tabular}


Tabel 6. Analisis probabilitas fasa pada kelompok C

\begin{tabular}{cccccc}
\hline \multicolumn{2}{c}{ Observasi } & \multicolumn{3}{c}{ Referensi } \\
\hline No. Puncak & $d(\AA)$ & $d(\AA)$ & $h k l$ & Fasa & No. Referensi \\
\hline 13 & 3,1905 & 3,1992 & 002 & $(\mathrm{Na}, \mathrm{K}) \mathrm{AlSi}_{3} \mathrm{O}_{8}$ & PDF \# 83-2215 \\
26 & 2,1558 & 2,1628 & 060 & $(\mathrm{Na}, \mathrm{K}) \mathrm{AlSi}_{3} \mathrm{O}_{8}$ & PDF \# 83-2215 \\
28 & 2,0434 & 2,0361 & 241 & $(\mathrm{Na}, \mathrm{K}) \mathrm{AlSi}_{3} \mathrm{O}_{8}$ & PDF \# 83-2215 \\
\hline
\end{tabular}

Tabel 7. Analisis probabilitas fasa pertama pada kelompok D (fasa $\mathrm{Fe}_{3} \mathrm{O}_{4}$ ).

\begin{tabular}{cccccc}
\hline \multicolumn{2}{c}{ Observasi } & & & Referensi & \\
\hline No. Puncak & $d(\AA)$ & $d(\AA)$ & $h k l$ & Fasa & No. Referensi \\
\hline 22 & 2,5379 & 2,5322 & 311 & $\mathrm{Fe}_{3} \mathrm{O}_{4}$ & PDF \# 79-0418 \\
27 & 2,1034 & 2,0996 & 400 & $\mathrm{Fe}_{3} \mathrm{O}_{4}$ & PDF \# 79-0418 \\
33 & 1,7164 & 1,7143 & 422 & $\mathrm{Fe}_{3} \mathrm{O}_{4}$ & PDF \# 79-0418 \\
39 & 1,2807 & 1,2807 & 533 & $\mathrm{Fe}_{3} \mathrm{O}_{4}$ & PDF \# 79-0418 \\
\hline
\end{tabular}

Tabel 8. Analisis probabilitas fasa kedua pada kelompok D (fasa $\mathrm{FeTiO}_{3}$ )

\begin{tabular}{cccccc}
\hline \multicolumn{2}{c}{ Observasi } & \multicolumn{3}{c}{ Referensi } \\
\hline No. Puncak & $d(\AA)$ & $d(\AA)$ & $h k l$ & Fasa & No. Referensi \\
\hline 22 & 2,5379 & 2,5415 & $\overline{1} 10$ & $\mathrm{FeTiO}_{3}$ & PDF \# 75-0519 \\
27 & 2,1034 & 2,1000 & 020 & $\mathrm{FeTiO}_{3}$ & PDF \# 75-0519 \\
33 & 1,7164 & 1,7205 & 231 & $\mathrm{FeTiO}_{3}$ & PDF \# 75-0519 \\
39 & 1,2807 & 1,2800 & 241 & $\mathrm{FeTiO}_{3}$ & PDF \# 75-0519 \\
\hline
\end{tabular}

Jika dikomparasikan dengan hasil studi pXRF sebelumnya (Purawiardi, Purawiardi dan Firdiyono, 2020), didapatkan suatu fakta yaitu hasil analisis XRD menggunakan metode pelebaran puncak difraksi ini dapat mendeteksi mineral-mineral non bijih nefelin dan lueneburgit yang tidak dapat dideteksi sebelumnya dengan karakterisasi pXRF. Selain itu, hasil analisis studi ini juga memiliki kelebihan yaitu dapat menentukan jenis mineral albit yang terkandung pada pasir besi titan Yogyakarta, yaitu jenis albit tingkat tinggi yang pada hasil karakterisasi pXRF tidak dapat ditentukan jenis albitnya. Namun, hasil analisis pada studi ini juga memiliki kekurangan yaitu tidak dapat mendeteksi adanya mineral bijih hematit serta mineral-mineral non-bijih hipersten, augit, kuarsa, dan biotit yang justru dapat diidentifikasi dari karakterisasi pXRF. Oleh sebab itu, hasil analisis mineral pada studi kali ini dapat digabungkan dengan hasil karakterisasi mineral menggunakan pXRF pada studi sebelumnya menjadi sebuah interpretasi gabungan sehingga dapat dihasilkan hasil analisis probabilitas mineralnya secara lebih maksimal.

\section{KESIMPULAN}

Berdasarkan analisis pelebaran puncak difraksi sinar-x menggunakan metode plot WilliamsonHall dapat disimpulkan beberapa hal sebagai berikut:

1. Probabilitas mineral-mineral bijih yang terkandung dalam pasir besi titan Yogyakarta adalah $\mathrm{Fe}_{3} \mathrm{O}_{4}$ (magnetit) dan $\mathrm{FeTiO}_{3}$ (ilmenit).

2. Probabilitas mineral-mineral non-bijih yang terkandung pada pasir besi titan Yogyakarta adalah $\mathrm{Na}_{3} \mathrm{~K}(\mathrm{Al}, \mathrm{Si})_{8} \mathrm{O}_{16} \quad$ (nefelin), $\mathrm{Mg}_{3} \mathrm{~B}_{2}(\mathrm{OH})_{6}\left(\mathrm{PO}_{4}\right)_{2}\left(\mathrm{H}_{2} \mathrm{O}\right)_{6}$ (lueneburgit), dan $(\mathrm{Na}, \mathrm{K}) \mathrm{AlSi}_{3} \mathrm{O}_{8}$ (albit tingkat tinggi).

3. Puncak-puncak difraksi mineral-mineral non-bijih (nefelin, lueneburgit, dan albit tingkat tinggi) mengalami pelebaran akibat efek dari regangan kisi dan ukuran kristalit, sedangkan pelebaran puncak-puncak difraksi mineral-mineral bijih hanya diakibatkan oleh efek regangan kisi saja.

4. Hasil analisis pelebaran puncak difraksi XRD dan hasil karakterisasi pXRF samasama dapat mendeteksi adanya mineralmineral bijih magnetit dan ilmenit, serta mineral non-bijih albit. 
5. Hasil analisis pelebaran puncak difraksi XRD dapat mendeteksi mineral-mineral non-bijih nefelin dan lueneburgit yang tidak dapat diidentifikasi dari karakterisasi pXRF, namun tidak dapat mendeteksi mineral bijih hematit serta mineral-mineral nonbijih seperti hipersten, augit, kuarsa, dan biotit yang justru dapat diidentifikasi dari karakterisasi pXRF. Oleh karena itu hasil analisis dapat digabungkan untuk memperoleh interpretasi hasil yang lebih lengkap.

\section{UCAPAN TERIMA KASIH}

Ucapan terima kasih ditujukan kepada Saudara Ciswandi, Rifqo Anwarie dan Arda Yogatama dari PT. Multiteknindo Infotronika atas fasilitas pengujian XRD dan perangkat lunak HSP.

\section{DAFTAR PUSTAKA}

Aarif UI Islam, S. dan Ikram, M. (2019) "Structural stability improvement, Williamson Hall analysis and band-gap tailoring through A-site Sr doping in rare earth based double perovskite La2NiMnO6," Rare Metals, 38(9), hal. 805813. doi: 10.1007/s12598-019-01207-4.

Dey, P. C. dan Das, R. (2021) "Impact of silver doping on the crystalline size and intrinsic strain of MPA-capped CdTe nanocrystals: A study by Williamson-Hall method and sizestrain plot method," Journal of Materials Engineering and Performance, 30(1), hal. 652660. doi: 10.1007/s11665-020-05358-9.

Erdoğan, E. (2019) "X-ray line-broadening study on sputtered InGaN semiconductor with evaluation of Williamson-Hall and size-strain plot methods," Indian Journal of Physics, 93(10), hal. 1313-1318. doi: 10.1007/s12648019-01403-z.

Kafashan, H. (2019) "X-ray diffraction line profile analysis of undoped and Se-doped SnS thin films using Scherrer's, Williamson-Hall and size-strain plot methods," Journal of Electronic Materials, 48(2), hal. 1294-1309. doi: 10.1007/s11664-018-6791-7.
Kulkarni, A. B. dan Mathad, S. N. (2018) "Synthesis and structural analysis of $\mathrm{Co}-\mathrm{Zn}-\mathrm{Cd}$ ferrite by Williamson-Hall and size-strain plot methods," International Journal of SelfPropagating High-Temperature Synthesis, 27(1), hal. 37-43. doi: 10.3103/S106138621801003X.

Kumar, R. (2017) "Characterisation of minerals and ores: On the complementary nature of select techniques and beyond," Transactions of the Indian Institute of Metals, 70(2), hal. 253-277. doi: 10.1007/s12666-016-1006-5.

Madhavi, J. (2019) "Comparison of average crystallite size by X-ray peak broadening and Williamson-Hall and size-strain plots for $\mathrm{VO} 2+$ doped $\mathrm{ZnS} / \mathrm{CdS}$ composite nanopowder," SN Applied Sciences, 1(11), hal. 1509. doi: 10.1007/s42452-019-1291-9.

Norouzzadeh, P., Mabhouti, K., Golzan, M. M. dan Naderali, R. (2020) "Consequence of $\mathrm{Mn}$ and $\mathrm{Ni}$ doping on structural, optical and magnetic characteristics of $\mathrm{ZnO}$ nanopowders: the Williamson-Hall method, the Kramers-Kronig approach and magnetic interactions," Applied Physics A, 126(3), hal. 154.

doi: 10.1007/s00339-020-3335-9.

Pratapa, S. dan O'Connor, B. (2002) “Development of $\mathrm{MgO}$ ceramic standards for x-ray and neutron line broadening assessments," Denver $X$-ray Conference: Advances in X-ray Analysis, 45 , hal. 41-47.

Purawiardi, I., Purawiardi, R. dan Firdiyono, F. (2020) "Probabilitas mineral pasir besi titan Yogyakarta berdasarkan studi pXRF," Jurnal Teknologi Mineral dan Batubara, 16(1), hal. 15-21. doi: 10.30556/jtmb.Vol16.No1.2020.1064.

Pushkarev, S. S., Grekhov, M. M. dan Zenchenko, N. V. (2018) "X-ray diffraction analysis of features of the crystal structure of GaN/Al0.32Ga0.68N HEMT-Heterostructures by the WilliamsonHall method," Semiconductors, 52(6), hal. 734-738. doi: 10.1134/S1063782618060209.

Suryanarayana, C. dan Norton, M. G. (1998) X-ray diffraction: A practical approach. 1 ed. New York: Plenum Press. 
